\title{
ASSESSMENT OF RESPIRATORY MUSCLE PERFORMANCE, FUNCTIONAL CAPACITY, FATIGUE, AND QUALITY OF LIFE IN LIVER TRANSPLANT CANDIDATES
}

\author{
Avaliação da musculatura respiratória, capacidade funcional, fadiga e qualidade de vida \\ em candidatos a transplante de fígado
}

\author{
Cristina Aparecida Veloso-Guedes, Ilka de Fátima Santana Ferreira Boin, Sebastião Araújo, \\ Luciana Castilho de Figueirêdo, Stela Talazzo Rosalen, Ana Beatriz Sasseron
}

\begin{abstract}
Purpose: This study aimed at assessment of respiratory muscle performance (RMP), functional capacity (FC), feeling of fatigue, and quality of life (QOL) in liver transplant candidates and to correlate these variables with each other and with the Model for End-Stage Liver Disease (MELD). Methods: A prospective study carried out from January/2008 to June/2009 including 130 liver transplant candidates on waiting-list at the São Paulo Health Transplant System, followed at the Unit of Liver Transplantation - Unicamp with cirrhosis of any etiology, independent of gender, age, and degree of liver function impairment as classified by the MELD score. Respiratory muscle performance was determined by respiratory muscle strength (RMS - PIMAX and PEMAX), vital capacity (VC), and FC measured during six-minute walk tests (6MWT). Fatigue was evaluated using the Fatigue Severity Scale (FSS), and QOL was assessed using the SF-36 questionnaire. Results: Expressed as the mean \pm SD and percentage of the predicted value: $M E L D=16 \pm 4$, $\mathrm{VC}=4.0 \pm 0.9 \mathrm{~L}-(97 \% \pm \pm 16 \%), \mathrm{PIMAX}=77 \pm 28 \mathrm{cmH} 2 \mathrm{O}-(71 \pm 25 \%), \mathrm{PEMAX}=76 \pm 26 \mathrm{cmH} 2 \mathrm{O}(76 \pm 26 \%), 6 \mathrm{MWT}=453.9 \pm 81.2 \mathrm{~m}$ $(73 \pm 13 \%), F S S=34 \pm 17$, and compromised $Q O L$, particularly in physical (48 \pm 41$)$ and emotional (57 \pm 41$)$ aspects, vitality $(58 \pm 26)$ and general state $(58 \pm 24)$. Predicted VC was negatively correlated with MELD $(p=0.0034)$ and positively correlated with RMS and 6MWT $(p=0.0217)$. Greater distances in the 6MWT were associated with a higher RMS and QOL and less fatigue. Greater FSS scores resulted in lower QOL scores. Conclusion: A decrease in VC was related to the severity of liver disease and a decrease in RMS and FC, which, in turn, correlated with greater fatigue and lower QOL.
\end{abstract}

Keywords: Muscle Strength, Liver Transplantation, Fatigue, Quality of Life, Lung Volume Measurements

Institution:

Department of Surgery at the School of Medical Sciences University of Campinas (Unicamp) - Campinas - SP- Brazil

\section{Correspondence:}

Cristina Aparecida Veloso-Guedes

Av. Goffredo Teixeira Silva Telles, 1341 - casa 77

Jd. Universitário - Araras - SP - Brazil. Zip code: 13607-350

Phone: (55) 1933521692

E-mail: crisveloso@me.com or ilkaboin@gmail.com

Recebido em: 13/12/2016

Aceito em: 13/01/2017

\section{INTRODUCTION}

Patients with cirrhosis often experience loss of muscle mass and significant weakness related to the degree of organ function impairment., ${ }^{1,2}$ In the terminal stage of liver failure, patients may be significantly restricted in their daily activities, primarily due to fatigue. ${ }^{3-5}$

Until the late 1990s, the Child-Turcotte Pugh (CTP) classification was the prevailing model to evaluate chronic liver disease and determine whether a patient was a candidate for a liver transplant. ${ }^{4,5}$

In 2000, the Model for End-Stage Liver Disease (MELD) ${ }^{6}$ was adopted to predict survival. In Brazil, the MELD criteria are used to order wait-listed candidates since 2006, as implemented by the Ministerial Directive 1160/GM. ${ }^{7}$ 
Several authors have used the CTP classification to correlate the severity of liver disease with the decrease in functional capacity ${ }^{8,9}$ and quality of life. ${ }^{9-12}$ However, few authors have demonstrated the relationship between severity of liver disease and MELD. ${ }^{12,13}$

Even though pulmonary volume and capacity are not affected in transplant candidates, the respiratory muscles are compromised, ${ }^{14}$ and lower values of maximum inspiratory pressure evaluated in wait-listed candidates have been associated with shorter survival. ${ }^{15}$

Alterations in the skeletal muscle of patients with cirrhosis have been observed, though the degree of impairment and its relation to liver function, degree of fatigue, and quality of life have not been described.

Therefore, the aim of the present study was to assess respiratory muscle performance, functional capacity, feeling of fatigue, and quality of life in liver transplant candidates and to correlate these variables with severity and impairment of liver function (MELD).

\section{MATERIAL AND METHODS}

This project was approved by the Research Ethics Committee of the School of Medical Sciences at University of Campinas (REC-SMS-Unicamp) under protocol no. 666/2007.

The study included liver transplant candidates waitlisted in the São Paulo Health Department's Transplant System and monitored at the Liver Transplant Unit at Gastrocentro/Unicamp with cirrhosis of any etiology, independent of gender, age, and degree of liver function impairment as classified by the MELD score without exception points.

During the data collection period (January 2008 to June 2009), patients who developed unmanageable ascites or respiratory discomfort due to infections or were unable to comprehend verbal commands were excluded from the study.

Therefore, the final population consisted of 130 candidates who met the inclusion criteria, which, according to sample size calculation based on multivariate analysis of the variables to be analyzed, is a large enough sample size, as recommended by the Statistical Office at the SMS-Unicamp.

A questionnaire was applied for identification and medical history: age, gender, body mass index (BMI), diagnosis of liver disease, associated complications, medical history, habits (alcohol and smoking), and pulmonary antecedents.

Respiratory muscle strength (RMS) was determined by measuring the maximum inspiratory pressure (PIMAX) and maximum expiratory pressure (PEMAX) using a digital manovacuometer (MVD 300/Globalmed, Porto Alegre, Brazil), according to the technique and normality equations proposed by Neder et al. ${ }^{16}$ The vital capacity (VC) was evaluated using a digital ventilometer (Ventronic II/DHD Healthcare, Wampsville, NY, USA), according to the technique and reference equations proposed by Pereira et al. ${ }^{17}$

Functional capacity (FC) was evaluated by a six-minute walk test (6MWT) in a 20-meter long corridor. To normalize the data, values were corrected for weight, height, and gender according to Enright and Sherrill's equations. $^{18}$

The presence of fatigue was monitored using the fatigue severity scale (FSS), which consists of scores from 9 to 63 in which values $\geq$ to 28 were considered to indicate fatigue. A number between one ("strongly disagree") and seven ("strongly agree") was assigned to each statement based on the patient's response. ${ }^{19}$

To assess quality of life (QOL), a generic MOS SF-36 questionnaire (medical outcomes study 36 item shortform health survey) $)^{20-22}$ was used. The questionnaire consisted of 36 items grouped into 8 domains: functional capacity, physical aspects, pain, general health status, vitality, social aspects, emotional aspects, and mental health. A score was obtained for each patient and each domain by applying a scale with values between zero (high impairment) and 100 (no impairment).

Chi-square and Fisher's exact tests (for expected values below 5) were used to compare categorical variables between groups, and, because the variables did not show a normal distribution, the Mann-Whitney test was used to compare numerical variables. Spearman's correlation coefficient was used to analyze the relationship between numerical variables. A $5 \%$ level of significance was adopted in this study $(p<0.05)$.

\section{RESULTS}

One hundred and thirty liver transplant candidates were included in this study. Of these patients, 104 were men, and 26 were women, with an average age of $49.3 \pm$ 10.1 years ( $74 \%$ in the age range of 40 to 59 years) and average BMI of $27.4 \pm 4.4 \mathrm{~kg} / \mathrm{m} 2$.

Half the candidates $(54.4 \%)$ had a diagnosis of viral hepatitis C (VHC), associated or not to alcoholism, and alcohol consumption was the sole cause for cirrhosis in $23 \%$ of candidates. The remaining candidates had less common causes of cirrhosis.

Regarding the complications associated with liver disease, $77.7 \%$ of candidates presented esophageal varices with or without gastrointestinal bleeding. Ascites 
Cristina Aparecida Veloso-Guedes, Ilka de Fátima Santana Ferreira Boin, Sebastião Araújo, Luciana Castilho de Figueirêdo, Stela Talazzo Rosalen, Ana Beatriz Sasseron

was reported in $64.6 \%$ of cases; encephalopathy or neuropathy was reported in $44.6 \%$, bacterial peritonitis in $10 \%$, umbilical or inguinal hernia in $9.2 \%$, and hepatocellular carcinoma in $6.9 \%$ of cases.

Other prevalent medical conditions included systemic arterial hypertension ( $\mathrm{SAH}-23.1 \%$ of cases) and diabetes $(20.8 \%)$.

In the medical history questionnaire, $61.5 \%$ of candidates reported having consumed alcohol; $48.5 \%$ reported previous smoking, and $14.6 \%$ smoked at the time of the survey. Respiratory symptoms were present in $19.2 \%$ of cases. Acute or chronic coughing was reported in $10 \%$ of candidates, with a history of expectoration in $15.4 \%$. Shortness of breath at some point after the disease, which was usually associated with ascites, was reported by $47 \%$ of candidates.

The mean value of the MELD score was of $16.4 \pm 3.7$ (7$26)$ and the resting clinical variables were within normal mean value ranges (Table 1).

Both PIMAX and PEMAX were below the predicted values. The vital capacity was normal according and in the 6MWT the mean distance covered was below the predicted value. (Table 1).

Table 1: Descriptive analysis of MELD score, clinical variables, respiratory muscle performance, functional capacity, fatigue, and quality of life

\begin{tabular}{lccc}
\hline \multicolumn{1}{c}{ Variables } & $\mathbf{n}$ & Mean \pm SD & $\begin{array}{c}\text { \% of predicted } \\
\text { value }\end{array}$ \\
\hline MELD & 130 & $16.4 \pm 3.9$ & \\
Resting Rr (ipm) & 130 & $15.3 \pm 3.4$ & \\
Resting HR (bpm) & 130 & $69.6 \pm 14.3$ & \\
Resting MAP (mmHg) & 121 & $86.8 \pm 10.3$ & \\
Resting SpO2 (\%) & 130 & $97.1 \pm 1.9$ & \\
Vital Capacity (L) & 129 & $4.05 \pm 0.91$ & $97.4 \pm 15.8$ \\
PIMAX (cmH2O) & 130 & $77.0 \pm 28.5$ & $70.7 \pm 25.5$ \\
PEMAX (cmH2O) & 130 & $75.6 \pm 26.0$ & $64.7 \pm 20.4$ \\
Distance covered on the & 121 & $453.9 \pm 81.2$ & $73.0 \pm 13.5$ \\
6MWT(m) & & & \\
Fatigue Score & 130 & $34.0 \pm 17.1$ & \\
Quality of Life & & & \\
Functional Capacity & 130 & $61.7 \pm 25.4$ & \\
Physical Aspects & 125 & $47.6 \pm 41.1$ & \\
Pain & 125 & $66.8 \pm 26.7$ & \\
General State & 130 & $57.9 \pm 24.4$ & \\
Vitality & 129 & $57.8 \pm 25.6$ & \\
Social Aspects & 130 & $67.6 \pm 25.9$ & \\
Emotional Aspects & 124 & $57.0 \pm 40.9$ & \\
Mental Health & 129 & $64.5 \pm 25.3$ & \\
\hline
\end{tabular}

$n=$ number of subjects; $S D=$ standard deviation; $M E L D=$ Model for EndStage Liver Disease; $R r=$ respiratory rate; $H R=$ heart rate; $M A P=$ mean arterial pressure; $S p O 2=$ peripheral oxygen saturation; $P I M A X=$ maximum inspiratory pressure; PEMAX = maximum expiratory pressure; $6 M W T-$ sixminute walk test
Scores evaluated by the FSS revealed fatigue in these candidates, and the assessment of QOL showed impairment in eight domains of the SF-36 (Table 1).

A significant difference was observed between the ranges of MELD scores relative to the incidence of alcoholism $(p=0.004)$, showing a higher frequency of alcoholism in candidates with MELD scores $\leq 16(73.8 \%$ x 49.2\%).

Patients with MELD scores $\leq 16$ had a higher frequency of chronic coughing $(13.9 \% \times 6.1 \%)$ whereas those with MELD scores $>16$ presented more acute coughing $(27.7 \% \times 10.8 \%, p=0.028)$. Higher VC values were observed in candidates with MELD scores $\leq 16(100 \pm$ $15.4 \% \times 95 \pm 15.9 \%$ ).

The percentage of the predicted distance covered in the 6MWT showed a positive correlation with age, BMI, MAP, predicted VC, and RMS. (Table 2)

A negative correlation was observed between fatigue and the distance covered in the 6MWT. (Table 2)

Among the eight domains assessed by the SF-36 questionnaire, six were positively correlated with the percentage of the predicted distance covered in the 6MWT (Table 2).

Table 2: Correlation analysis of the studied variables and the percentage of the predicted distance covered in the $6 \mathrm{MWT}$

\begin{tabular}{lccc}
\hline \multicolumn{1}{c}{ Variables } & $\mathbf{n}$ & $\mathbf{r}$ & $\mathbf{p}$ \\
\hline Age & 121 & 0.2863 & 0.0015 \\
BMI & 121 & 0.2294 & 0.0114 \\
MAP & 121 & 0.1990 & 0.0286 \\
Respiratory performance & & & \\
Predicted vital capacity & 120 & 0.2094 & 0.0217 \\
PIMAX & 121 & 0.2342 & 0.0097 \\
Predicted PIMAX & 121 & 0.3495 & $<0.0001$ \\
PEMAX & 121 & 0.2336 & 0.0099 \\
Predicted PEMAX & 121 & 0.3782 & $<0.0001$ \\
Fatigue score & 121 & -0.2051 & 0.0240 \\
Quality of life & & & \\
Functional Capacity & 121 & 0.3188 & 0.0004 \\
Physical Aspects & 116 & 0.2870 & 0.0018 \\
General State & 121 & 0.2414 & 0.0076 \\
Vitality & 121 & 0.1907 & 0.0362 \\
Social Aspects & 121 & 0.2599 & 0.0040 \\
Emotional Aspects & 115 & 0.2284 & 0.0141 \\
\hline
\end{tabular}

$n=$ number of subjects;

$r=$ Spearman's correlation coefficient;

$p=p$-value $B M I=$ body mass index;

$M A P=$ mean arterial pressure; $P I M A X=$ maximum inspiratory pressure;

PEMAX = maximum expiratory pressure.

The table shows only variables with statistically significant correlations. 
Predicted VC was the only variable that correlated with the MELD score. This was a negative correlation.(Table 3)

Table 3: Correlation analysis of the studied variables with the percentage of predicted vital capacity

\begin{tabular}{|l|c|c|c|}
\hline \multicolumn{1}{|c|}{ Variables } & $\mathbf{n}$ & $\mathbf{r}$ & $\mathbf{p}$ \\
\hline MELD & 129 & -0.2558 & 0.0034 \\
\hline PIMAX & 129 & 0.2999 & 0.0006 \\
\hline Predicted PIMAX & 129 & 0.2983 & 0.0006 \\
\hline PEMAX & 129 & 0.2200 & 0.0122 \\
\hline Predicted PEMAX & 129 & 0.2140 & 0.0149 \\
\hline 6MWT & 120 & 0.2062 & 0.0238 \\
\hline Predicted 6MWT & 120 & 0.2094 & 0.0217 \\
\hline
\end{tabular}

$n=$ number of subjects; $r=$ Spearman's correlation coefficient; $p=p$-value; $M E L D=$ Model for End-Stage Liver Disease; PIMAX = maximum inspiratory pressure; $P E M A X=$ maximum expiratory pressure; $6 M W T=$ 6-minute walk test.

Variables that assessed RMS showed a positive correlation with predicted VC. A positive correlation was also observed for both absolute and predicted values of distance covered in the 6MWT (Table 3).

Fatigue scores showed a negative correlation with the SF-36 domains. The greater the feeling of fatigue reported, the greater the impairment of QOL in all aspects (Table 4).

Table 4: Correlation analysis of the fatigue score variables

\begin{tabular}{lccc}
\hline \multicolumn{1}{c}{ Variables } & $\mathbf{n}$ & $\mathbf{r}$ & $\mathbf{p}$ \\
\hline Predicted 6MWT & 121 & -0.2051 & 0.0240 \\
Quality of Life & & & \\
Functional Capacity & 130 & -0.6675 & $<0.0001$ \\
Physical Aspects & 125 & -0.5789 & $<0.0001$ \\
Pain & 125 & -0.4165 & $<0.0001$ \\
General State & 130 & -0.5576 & $<0.0001$ \\
Vitality & 129 & -0.6923 & $<0.0001$ \\
Social Aspects & 130 & -0.4991 & $<0.0001$ \\
Emotional Aspects & 124 & -0.5130 & $<0.0001$ \\
Mental Health & 129 & -0.5573 & $<0.0001$ \\
\hline
\end{tabular}

$n=$ number of subjects; $r=$ Spearman's correlation coefficient; $p=p$-value; $6 M W T=6$-minute walk test.

The table shows only variables that had statistically significant correlations

\section{DISCUSSION}

The implementation of rehabilitation programs at the unit of transplantation can lead to better post transplant results or reduce the patients morbidities on waiting list. The majority of transplant candidates in the present study were male and over 40 years-old, and the main causes of cirrhosis were hepatitis B or C, associated or not with the consumption of alcohol. These findings are consistent with other national ${ }^{14,15,21}$ and international studies. $^{10,12,22-25}$

The results showed a high incidence of complications of cirrhosis. The high incidence of complications while waiting for a transplant represents greater impairment in liver function and a worsening of $\mathrm{FC},{ }^{9} \mathrm{QOL},{ }^{10}$ and fatigue. ${ }^{26-28}$

Alcohol and tobacco abuse were frequent in the studied population. Almost half the candidates reported dyspnea after the disease was diagnosed, which was most often associated with ascites, which leads to dyspnea by altering the respiratory mechanics and compromising gas exchange. ${ }^{28,29}$

The MELD scores demonstrated a significant degree of impairment in liver function. ${ }^{30}$ However, the clinical variables were normal, indicating a stable population from a clinical point of view on the day of assessment.

In the present study, despite the impairment of RMS, VC did not change in relation to the predicted values.

Various studies have reported that impairment of pulmonary volume and capacity are not present in the majority of liver transplant candidates, even when a loss in preoperative RMS is observed. ${ }^{12,14,29}$

It has been demonstrated that a decrease in VC is observed when there is a significant reduction of RMS (higher than 50\%), ${ }^{29,30}$ which probably explains the absence of significant changes in $\mathrm{VC}$ in the present study.

Carvalho et al. ${ }^{15}$ correlated RMS and mortality in waitlisted liver transplant candidates and showed that the RMS were decreased; however, only PIMAX showed a relationship with mortality, suggesting that RMS can be used as a predictor of severity.

We are suggesting that RMS and VC should be assessed periodically for early diagnosis and preoperative therapy.

Functional capacity was also shown to be impaired, with a loss of approximately $30 \%$ compared to the predicted distance covered by normal individuals. ${ }^{17,18}$

In other studies, the distance covered in the 6MWT by patients with cirrhosis was significantly smaller than that of normal individuals. , $^{9,23,24}$

In addition to evaluating physical performance, the distance covered in a 6MWT may also serve as a prognostic indicator for patients with liver disease. ${ }^{10} \mathrm{~A}$ recent study has demonstrated that distances less than 250 meters covered in a 6MWT are associated with significantly increased risk of death on wait lists and after liver transplant. ${ }^{30}$ 
The average FSS score showed a significant degree of fatigue and the assessment of QOL by the SF36 questionnaire showed impairment in all domains, especially physical, emotional, vitality and general state, in the studied population.

Fatigue can be severe in patients with chronic liver disease. Although its pathophysiology is still unknown, it could be of central origin, resulting from changes in the serotonin neurotransmitter system, rather than peripheral, given that it is not always associated with muscle weakness. ${ }^{31-34}$

For many years, the success in organ transplantation had been measured by mortality rates, complications in biliary anastomoses, and infections. Recently, the concern has been focused on improving the QOL in these patients. ${ }^{35-43}$

Several authors have reported an important loss in QOL in transplant candidates using both the generic SF-36 questionnaire $8,13,32,33$ and questionnaires specific for liver disease. . $^{10,14,44,45}$

Recent studies have shown that the MELD score is not a good predictor of QOL because it does not take into account the presence of ascites or encephalopathy. ${ }^{8-11,25}$ According to Freeman, ${ }^{39}$ the MELD score was developed to measure the risk of mortality in chronic liver disease, but not to measure QOL. The author, therefore, suggested that these two tools are complementary in assessing the general condition of the candidates. ${ }^{39,40}$

In the present study, the correlation analysis between the variables and the ${ }^{8}$ and RMP. Fatigue scores were negatively correlated with the 6MWT and with all the domains evaluated in the SF-36 questionnaire, indicating that the greater the feeling of fatigue, the greater the impairment in QOL and the worse the FC, as evaluated by the 6MWT.

According to Dharancy et al, ${ }^{12}$ cardiorespiratory aptitude seemed to be affected by the severity of liver insufficiency (MELD $\geq 15.2$ ), age ( $\geq 52$ years), gender (women), hemoglobin level $(<11.3 \mathrm{~g} / \mathrm{dL})$, and tobacco abuse.

Teuber et al. ${ }^{31}$ found a significant association between the physical aspects assessed by the SF-36 questionnaire and fatigue and the degree of fibrosis in patients with chronic VHC infections.

Wiesinger et al. ${ }^{8}$ demonstrated that the consumption of oxygen in patients with advanced stages of liver disease was significantly smaller than the predicted values for the normal population, which limits FC in these patients during everyday life activities and is perceived as a feeling of fatigue and inability to perform tasks easily accomplished before the disease, as confirmed by the SF-36 questionnaire. ${ }^{8}$
A correlation between fatigue and $\mathrm{QOL}$ has been observed in other studies. ${ }^{42-40}$ However, some studies showed no correlation between fatigue and the degree of liver impairment but rather with depression and the mental aspects of the questionnaire.$^{31,42}$ This correlation was also observed in the present study because fatigue was associated with lower scores in all domains of the SF-36 questionnaire.

A study ${ }^{13}$ found that low scores for physical components of the SF-36 questionnaire were associated with increased mortality in liver transplant candidates and suggested that the perception of the physical components are important determinants for the survival of the candidates, in addition to the severity of liver disease, and can be complementary to the MELD score.

According to Beyer et al., ${ }^{23}$ low aerobic capacity is associated with increased mortality after transplantation. Oxygen consumption is severely affected in transplant candidates and is associated with a decrease in survival, longer hospitalization, and greater postoperative need for oxygen, suggesting that respiratory rehabilitation programs should be implemented in the preoperative period..$^{13}$ Similar results were observed by other authors. ${ }^{45}$ Physical activity has been shown to significantly improve QOL in transplant patients. ${ }^{25,42}$ Identifying transplant candidates with low scores on physical aspects and promoting therapeutic interventions may prolong or improve their lives. Therefore, determining whether interventions are feasible for this population is an important area of study.

One of the limitations of this study was the performance of the 6MWT in a 20-meter long corridor. The American Thoracic Society (ATS) ${ }^{42}$ advocates the use of at least a 30-meter long track, emphasizing that smaller corridors make patients change directions more often, thus losing time and covering shorter distances, altering the test results. ${ }^{43-45}$ However, the results obtained from a pilot study conducted with 10 patients showed no significant difference between the mean distances covered by patients in a 20 -meter long corridor and a 30 -meter long corridor. ${ }^{43}$

\section{CONCLUSION}

Lung volume measurements, the feeling of fatigue, and QOL were impaired in liver transplant candidates, below the predicted values for normal individuals. However, there was no correlation with the severity of liver disease evaluated by the MELD score.

A decrease in VC was related to the severity of liver disease and a decrease in RMS and FC, which, in turn, correlated with greater fatigue and lower QOL. 


\section{RESUMO}

Objetivo: Avaliar o desempenho muscular respiratório (PGR), capacidade funcional (FC), sensação de fadiga e qualidade de vida (QV) em candidatos a transplante hepático e correlacionar essas variáveis entre si e com o modelo para a doença hepática em fase final. Métodos: Trata-se de estudo prospectivo, realizado entre janeiro/2008 e junho/2009, incluindo 130 candidatos a transplante hepático na lista de espera no Sistema Estadual de Transplante do Estado de São Paulo, acompanhados na Unidade de Transplante Hepático da UNICAMP, portadores de cirrose de qualquer etiologia, independente de sexo, idade e grau de comprometimento da função hepática classificada pelo escore MELD. O desempenho muscular respiratório foi determinado pela força muscular respiratória (FMR-PIMAX e PEMAX), capacidade vital (CV) e capacidade funcional (CF) foram medidos durante os testes de caminhada de seis minutos (TC6). A fadiga foi avaliada por meio da escala de gravidade da fadiga (FSS), e a Qualidade de vida (QV) foi avaliada pelo questionário SF-36. Resultados: MELD = 16 $\square$; CV $=4,0 \square 0,9 \mathrm{~L}-(97 \%(16 \%)$, PIMAX $=77 \square 28 \mathrm{cmH} 2 \mathrm{O}-$ $(71 \square 25 \%)$, PEMAX $=76 \square 26 \mathrm{cmH} 2 \mathrm{O}-(76 \square 26 \%), 6 \mathrm{MWT}=453,9 \square 81.2 \mathrm{~m}-(73 \square 13 \%), \mathrm{FSS}=34 \square 17$ e QV comprometida,

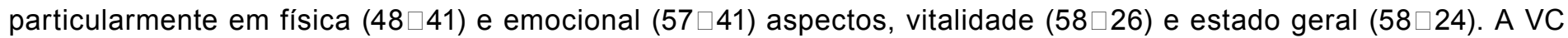
predita correlacionou-se negativamente com o MELD $(p=0.0034)$ e correlacionou-se positivamente com o FMR e o TC6 $(p=0.0217)$. Maiores distâncias no TC6 foram associadas à maior FMR, QV e menor fadiga. Maiores escores de FSS resultaram em menores escores de QV. Conclusão: A diminuição da CV esteve relacionada à gravidade da doença hepática e ao comprometimento pulmonar e correlacionou-se com maior fadiga e menor QV.

Descritores: Impacto Psicossocial; Transplante de Fígado; Psicologia.

\section{REFERENCES}

1. Andersen $\mathrm{H}$, Borre M, Jakobsen J, Heden Andersen $\mathrm{P}$, Vilstrup $\mathrm{H}$. Decreased muscle strength in patients with alcoholic liver cirrhosis in relation to nutritional status, alcohol abstinence, liver function and neuropathy. Hepatology. 1998;27(5):1200-7.

2. Rodes J, Navasa M. Liver transplantation and quality of life. Can J Gastroenterol. 2000;14(8):693-9.

3. Schlenk EA, Erlen JA, Dunbar-Jacob J, McDowell J, Engberg $S$, Sereika SM, et al. Health-related quality of life in chronic disorders: a comparison across studies using the MOS SF-36. Qual Life Res. 1998;7(1):57-65.

4. Pugh RNH, Muray Lyon IM, Dawson JL, Pietroni MC, Williams $\mathrm{R}$. Transaction of the oesophagus for bleeding oesophageal varices. Br J Surg. 1973;60(8):646-9.

5. Boin IFSF, Leonardi MI, Udo EY, Pereira TS, Stucchi RSB, Leonardi LS. The application of MELD score in patients submitted to liver transplantation: a retrospective analysis of survival and the predictive factors in the short and long term. ArqGastroenterol. 2008;45(4):275-83.

6. Malinchoc M, Kamath PS, Gordon FD, Peine CJ, Rank J, ter Borg PC. A model to predict survival in patients undergoing transjugular intrahepatic portosystemic shunts. Hepatology. 2000;31(4):864-71.
7. Brazil, Republic Presidency, Ministry of Health. Ministerial Directive no. 1.160 of May 29th, 2006. Criteria for the distribution of liver from deceased donors for transplantation. Union's Official Journal, Brasília (DF) 2006 May 31 no.103.

8. Wiesinger GF, Quittan M, Zimmermmann K,Nuhr M, Wichlas $M$, Bodingbauer $M$, et al. Physical performance and healthrelated quality of life in men on liver transplantation waiting list. J Rehabil Med. 2001;33(6):260-5.

9. Alameri HF, Sanai FM, Dukhayil M, Azzam NA, Al-Swat KA, Hersi AS, et al. Six minute walk test to assess functional capacity in chronic liver disease patients. World J Gastroenterol. 2007;13(29):3996-4001.

10. Saab S, Ibrahim AB, Shpaner A,Younossi ZM, Lee C, Durazo F, et al. MELD fails to measure quality of life in liver transplant candidates. Liver Transpl. 2005;11(2):218-23.

11. Younossi ZM, Boparai N, Price LL, Kiwi ML, McCormick M, Guyatt G. Health-related quality of life in chronic liver disease: the impact of type and severity of disease. Am J Gastroenterol. 2001;96(7):2199-205.

12. Dharancy S, Lemyze M, Boleslawski E,Neviere R, Declerck $\mathrm{N}$, Canva V, et al. Impact of impaired aerobic capacity on liver transplant candidates. Transplantation. 2008; 86(8):1077-83. 
Cristina Aparecida Veloso-Guedes, Ilka de Fátima Santana Ferreira Boin, Sebastião Araújo, Luciana Castilho de Figueirêdo, Stela Talazzo Rosalen, Ana Beatriz Sasseron

13. Tanikella R, Kawut SM, Brown Jr RS, Krowka MJ, Reinen J, Dinasarapu CR. Health-related quality of life and survival in liver transplant candidates. Liver Transpl. 2010;16(2):238-45.

14. Barcelos S, Dias AS, Forgiarini Jr. LA, Monteiro MB. Liver transplantation: effects in pulmonary capacity, functional condition and quality of life. ArqGastroenterol. 2008;45(3):186-191.

15. Carvalho EM, Isern MRM, Lima PA, Machado CS, Biagini AP, Massarollo PCB. Muscle strength and mortality while on a liver transplant waiting list. Rev Bras Fisioter. 2008;12(3):235-240.

16. Neder JA, Andreoni S, Castelo-Filho A, Nery LE. Reference values for lung function tests. I. Static volumes. Braz J Med Biol Res. 1999;32(6):703-717.

17. Pereira CAC, Barreto SP, Simões JG, Pereira FWL, Gerstler JG, Nakatani J. Reference values for spirometry in Brazilian adults. J Pneumol 1992;18(1):10-22.

18. Enright PL, Sherrill DL. Reference equations for the sixminute walk in healthy adults. Am J RespirCrit Care Med. 1998;158(5 Pt 1):1384-1387.

19. Krupp LB, LaRocca NG, Muir-Nash JM, Steinberg AD. The fatigue severity scale.Application to patients with multiple sclerosis and systemic lupus erythematosus. Arch Neurol. 1989;46(10):1121-1123.

20. Ciconelli RM, Ferraz MB, Santos W, Meinão I, Quaresma MR. Brazilian-Portuguese version of the SF-36. A reliable and valid quality of life outcome measure. Rev Bras Reumatol. 1999;39(3):143-150.

21. Leitão AVA, Castro CLN, Basile TM, Souza THS, Braulio VB. Evaluation of the nutritional status and physical performance in candidates to liver transplantation. Rev Assoc Med Bras. 2003;49(4):424-428.

22. Pieber K, Crevenna R, Nuhr MJ,Quittan M, PeckRadosavljevic V, Wesinger GF. Aerobic capacity, muscle strength and health-related quality of life before and after orthotopic liver transplantation: preliminary data of an Austrian transplantation centre. J Rehabil Med. 2006;38(5):322-328.

23. Beyer N, Aadahl M, Strange B,Kirkegaard P, Hansen BA, Mohr T, et al. Improved physical performance after orthotopic liver transplantation. Liver Transpl Surg. 1999;5(4):301-309.

24. Marchesini G, Bianchi G, Amodio P, Salerno F, Marli M, Panella $C$, et al. Factors associated with poor health-related quality of life of patients with cirrhosis. Gastroenterology. 2001;120(1):170-178.

25. Les I, Doval E, Flavià M, Jacas C, Cárdenas C, Esteban R, et al. Quality of life in cirrhosis is related to potentially treatable factors. Eur J GastroenHepat. 2010;22(2):221-227.

26. Jones DEJ, Bhala N, Burt J, Goldblatt J, Prince M, Newton $\mathrm{JL}$. Four year follow up of fatigue in a geographically defined primary biliary cirrhosis patient cohort. Gut. 2006;55(4):536541.
27. Merion RM. When is a patient too well and when is a patient too sick for a liver transplant? Liver Transpl. 2004;10(2):S69-S73.

28. McAlister FA, Bertsch K, Man J, Bradley J, Jacka M. Incidence of and risk factors for pulmonary complications after nonthoracic surgery. Am J RespirCrit Care Med. 2005;171(5):514-517.

29. Carey EJ, Steidley DE, Aqel BA, Byrne TJ, Mekeel KL, Rakela J, et al. Six-minute walk distance predicts mortality in liver transplant candidates. Liver Transpl. 2010;16(12):13731378.

30. Jones EA. Fatigue complicating chronic liver disease. Metab Brain Dis. 2004;19(3-4):421-429.

31. Teuber G, Schäfer A, Rimpel J, Paul K, Keicher C, Scheurlen $\mathrm{M}$, et al. Deterioration of health-related quality of life and fatigue in patients with chronic hepatitis $\mathrm{C}$ : association with demographic factors, inflammatory activity, and degree of fibrosis. J Hepatol. 2008;49(6):923-9.

32. Bonkovsky HL, Snow KK, Malet PF, Back-Madruga C, Fontana RJ, Sterling RK, et al. Health-related quality of life in patients with chronic hepatitis $\mathrm{C}$ and advanced fibrosis. $\mathrm{J}$ Hepatol. 2007;46(3):420-1.

33. Rodrigues RTS, Bruscato WL, Horta ALM, Nogueira-Martins LA. Preliminary study of quality of life and depressive symptomatology in pre- and post-transplant patients. Arq Bras CiencSaúde. 2008;33(2):74-78.

34. Gotardo DRM, Strauss E, Teixeira MCD, Machado MCC. Liver transplantation and quality of life: relevance of a specific liver disease questionnaire. Liver Int. 2008;28(1):99-106.

35. van der Plas SM, Hansen BE, Boer JB, Stijnen T, Passchier J, Man RA, et al. Generic and disease-specific health related quality of life in non-cirrhotic, cirrhotic and transplanted liver patients: a cross-sectional study. BMC Gastroenterol. 2003;3:33.

36. Telles-Correia D, Barbosa A, Mega I, Mateus E, Monteiro E. When does quality of life improve after liver transplantation? A longitudinal prospective study. Transplant Proc. 2009;41(3):904-905.

37. De Bona M, Ponton P, Ermani M,lemmolo RM, Feltrin $A$, Bocagni $P$, et al. The impact of liver disease and medical complications on quality of life and psychological distress before and after liver transplantation. J Hepatol. 2000;33(4):609-615.

38. Aberg F, Rissanen AM, Sintonen H, Roine RP, Höckerstedt $\mathrm{K}$, Isoniemi $\mathrm{H}$. Health-related quality life and employment status of liver transplant patients. Liver Transpl 2009;15(1):64-72.

39. Freeman RB. MELD and the quality of life. Liver Transpl. 2005;11(2):134-136.

40. Stanca CM, Bach N, Krause C, Tandon N, Freni MA, Gutierrez JÁ, et al. Evaluation of fatigue in US patients with primary biliary cirrhosis. Am J Gastroenterol. 2005;100(5):1104-1109. 
Assessment of respiratory muscle performance, functional capacity, fatigue, and quality of life in liver transplant candidates

41. Painter P, Krasnoff J, Paul SM, Ascher NL. Physical activity and health related quality of life in liver transplant recipients. Liver Transpl. 2001;7(3):213-219.

42. American Thoracic Society (ATS). ATS statement: guidelines for the six-minute walk test. Am J RespirCrit Care Med. 2002;166(1):111-117.

43. Veloso-Guedes CA, Rosalen ST, Thobias CM, Andreotti RM, Galhardo FD, Oliveira da Silva AM, et al. Validation of 20-meter corridor for the 6-minute walk test in men on liver transplantation waiting list. Transplant Proc. 2011;43(4):13221324.
44. Gudlaugsson J, Aspelund T, Gudnason V, Olafsdottir AS, Jansson PV, Arngrimsson SA, et al. The effects of 6 months'multimodal training on functional performance, strength, endurance, and body mass index of older individuals. Are the benefits of training similar among women and men? Laeknabladid 2013;99(7-8):331-7.

45. Faustini Pereira JL, Galant LH, Rossi D, Tellesda Rosa LH, Garcia E, de Mello Brandão AB, et al. Functional capacity, respiratory muscle strenght, and oxygen consumption predict mortality in patients with cirrhosis. Can J Gastroenterol Hepatol 2016:2016:6940374. Doi $10.1155 / 2016 / 6940374$. 